\title{
Biokinetics of zinc and cadmium accumulation and depuration at different stages in the life cycle of the cuttlefish Sepia officinalis
}

\author{
Paco Bustamante ${ }^{1, *}$, Jean-Louis Teyssié ${ }^{2}$, Scott W. Fowler ${ }^{2}$, Olivier Cotret ${ }^{2}$, \\ Bruno Danis ${ }^{3}$, Pierre Miramand ${ }^{1}$, Michel Warnau ${ }^{3, * *}$ \\ ${ }^{1}$ Laboratoire de Biologie et d'Environnement Marins, UPRES-EA 3168, Université de La Rochelle, \\ 22 Avenue Michel Crépeau, 17042 La Rochelle, France \\ ${ }^{2}$ Marine Environment Laboratory, International Atomic Energy Agency, 4 Quai Antoine Ier, PO Box 800, 98012 Monaco \\ ${ }^{3}$ Laboratoire de Biologie Marine (CP 160-15), Université Libre de Bruxelles, 50 Avenue F.D. Roosevelt, 1050 Brussels, Belgium
}

\begin{abstract}
Bioaccumulation of ${ }^{65} \mathrm{Zn}$ and ${ }^{109} \mathrm{Cd}$ by the cuttlefish Sepia officinalis L. was studied at different stages of its life cycle, i.e. in embryos, juveniles and adults, following exposures via sea water, sediments and food. Cuttlefish eggs efficiently accumulated both elements from seawater with bioconcentration factors of 79 for ${ }^{65} \mathrm{Zn}$ and 46 for ${ }^{109} \mathrm{Cd}$ after $11 \mathrm{~d}$ exposure. Most of the radiotracers were found in the capsule membrane of the eggs, demonstrating that the capsule acts as a shield to protect embryos against metals. Juveniles and adults efficiently bioconcentrated both radiotracers from seawater, with the muscular tissues containing $84 \%$ of the total ${ }^{65} \mathrm{Zn}$ and $62 \%$ of the total ${ }^{109} \mathrm{Cd}$. Loss kinetics followed a single exponential function for ${ }^{65} \mathrm{Zn}$, while for ${ }^{109} \mathrm{Cd}$ loss was best described by a double exponential model. Biological half-lives for elimination were ca. 2 mo for both elements. After $29 \mathrm{~d}$ depuration in uncontaminated seawater, 76 to $87 \%$ of the radiotracers were found in the digestive gland. For both elements, the dissolved phase can be considered as a significant source of accumulation. In an experiment with radiolabelled sediments, transfer factors were very low, even after $29 \mathrm{~d}$ exposure. Food-chain transfer experiments demonstrated that both juveniles and adults assimilated ${ }^{65} \mathrm{Zn}$ and ${ }^{109} \mathrm{Cd}$ very efficiently. Moreover, loss of ingested radiotracers was much slower than elimination of ${ }^{65} \mathrm{Zn}$ and ${ }^{109} \mathrm{Cd}$ taken up from seawater, indicating a very strong retention of dietary Cd and $\mathrm{Zn}$ by juvenile as well as by adult cuttlefish. As with direct uptake from seawater, ingested radiotracers were mainly found in the digestive gland, with fractions reaching $82 \%$ for ${ }^{65} \mathrm{Zn}$ and $97 \%$ for ${ }^{109} \mathrm{Cd}$ after $29 \mathrm{~d}$ depuration. These tracer experiments indicate that (1) food is the likely primary pathway for $\mathrm{Zn}$ and $\mathrm{Cd}$ bioaccumulation in $S$. officinalis, and (2) the digestive gland plays a major role in the subsequent storage and presumed detoxification of these elements regardless of the uptake pathway.
\end{abstract}

KEY WORDS: Zinc $\cdot$ Cadmium · Bioaccumulation - Depuration · Cephalopods · Sepia officinalis · Radiotracers

Resale or republication not permitted without written consent of the publisher

\section{INTRODUCTION}

Cephalopods constitute a class of marine molluscs which are found in a great variety of habitats from coastal waters to very deep ocean environments. They

*E-mail: pbustama@univ-lr.fr

** Present address: International Atomic Energy Agency Marine Environment Laboratory, 4 Quai Antoine Ier, PO Box 800, 98012 Monaco have also been found living under extreme conditions such as near hydrothermal vents (e.g. the hydrothermal octopus Vulcanoctopus hydrothermalis: Gonzalez et al. 1998). Cephalopods are benthic (e.g. octopusses), nectobenthic (cuttlefishes), neritic and pelagic (squids), and it follows that they are a primary food source for many marine predators such as marine mammals or seabirds (Clarke 1996, Croxall \& Prince 1996, Smale 1996).

Whatever their morphological and evolutionary diversity and heterogeneity in their geographic distribu- 
tion, cephalopods have in common the ability to concentrate Cd at extremely high levels (Martin \& Flegal 1975, Miramand \& Guary 1980, Finger \& Smith 1987, Miramand \& Bentley 1992, Bustamante et al. 1998a, 2000). Cephalopods are therefore a potential threat for higher trophic levels. Indeed, their predators are well known to display high $\mathrm{Cd}$ concentrations also (Bustamante et al. 1998b). The reason for such a high Cd bioaccumulation capacity is still poorly understood. Thus, the primary objective of the present work was to investigate the biokinetics of $\mathrm{Cd}$ uptake and elimination in cephalopods in order to better characterize their bioaccumulation, tissue distribution and retention capacity.

The common cuttlefish Sepia officinalis was selected as a model to study $\mathrm{Cd}$ transfer in cephalopods via sediments, seawater and food. Furthermore, bioaccumulation was followed at different stages of the life cycle of $S$. officinalis, viz. in embryos, early juveniles and adults, to better define the physiological basis for enhanced $\mathrm{Cd}$ bioconcentration.

In addition to $\mathrm{Cd}$, $\mathrm{Zn}$ was also considered in this study. This essential element has chemical properties similar to those of Cd that, in turn, could interfere with Zn metabolism (Nieboer \& Richardson 1980). Biokinetics were determined using carrier-free radiotracers in order to measure element fluxes in real time at environmentally realistic contaminant concentrations (Fisher et al. 1991, Warnau et al. 1996).

\section{MATERIALS AND METHODS}

Organisms. Eggs, newly hatched juveniles and adult common cuttlefish (Sepia officinalis L.) were used in the experiments. Cuttlefish eggs were obtained from the Marine Station of Banyuls sur Mer (France) and were maintained in an aquarium until hatching. Young cuttlefish were then kept in a separate aquarium (open circuit, $20 \mathrm{l} \mathrm{h}^{-1}$ flow rate, constant aeration, 38 psu, $16.5 \pm 0.5^{\circ} \mathrm{C}, 12: 12 \mathrm{~h}$ light:dark cycle) and fed with brine shrimp (Artemia sp.) for several days before the experiments.

In addition, 2 different groups of adults were investigated. The first group was reared in the Musée Océanographique (Principality of Monaco) from hatching to $1 \mathrm{yr}$ old organisms, and conditioned to feed on dead fishes and mussels. The second group consisted of adults collected by net-fishing off Monaco. They were maintained individually in aquaria for acclimation to laboratory conditions for $2 \mathrm{wk}$ prior to investigations. During acclimation, the wild cuttlefish were also conditioned on a diet of dead fishes and mussels.

In order to maintain the cuttlefish in good living conditions and to prevent cannibalism, food was provided ad libitum to both size classes before and during the experiments. Different food items were given to young and adult cuttlefish because of their specific biological characteristics: the diet of young individuals is restricted to small, relatively soft and fleshy crustaceans, while adults feed on larger crustaceans including crabs, molluscs (including cephalopods), and fishes (Boucher-Rodoni et al. 1987).

Prior to any experimentation, adults were anaesthetised in seawater containing $2 \%$ ethanol in order to determine their sex, weight and mantle length. At the same time, a numbered plastic marker was inserted into the mantle fin to identify each individual.

Radiotracers and radioanalyses. Carrier-free radiotracers, ${ }^{65} \mathrm{Zn}\left(T_{1 / 2}=243.9 \mathrm{~d}\right)$ and ${ }^{109} \mathrm{Cd}\left(T_{1 / 2}=462.6 \mathrm{~d}\right)$, were purchased from Amersham, UK. Stock solutions of ${ }^{65} \mathrm{Zn}$ and ${ }^{109} \mathrm{Cd}$ were prepared in $0.1 \mathrm{~N} \mathrm{HCl}$.

Activities of the radiotracers were measured using a high-resolution $\gamma$-spectrometry system consisting of coaxial Ge N or P type detectors (EGNC 33-195-R, Intertechnique) connected to a multichannel analyser and a PC employing spectral analysis software (Interwinner, Intertechnique). The absolute activities of the samples were determined by comparison with known standards of appropriate geometry and were corrected for background and physical decay of the radiotracers.

Counting times were adapted to obtain relative propagated errors $<5 \%$. However, in a few cases, this counting precision could not be obtained even after $48 \mathrm{~h}$ of counting due to the very low activity in some minute organs. Counting times ranged from $10 \mathrm{~min}$ to $1 \mathrm{~h}$ for whole cuttlefish, mussel and brine shrimp radioanalyses, and from $10 \mathrm{~min}$ to $48 \mathrm{~h}$ for the dissected tissues.

Experimental procedures. Contamination of Sepia officinalis through the sediments, seawater and food was determined as follows:

Contamination from sediments: A group of 9 newly hatched cuttlefish (mean wet weight $\pm \mathrm{SD}=0.327 \pm$ $0.063 \mathrm{~g}$ ) were placed for $29 \mathrm{~d}$ in a 201 plastic aquarium (open circuit, $20 \mathrm{l} \mathrm{h}^{-1}$ flow rate, constant aeration, $38 \mathrm{psu}, 16.5 \pm 0.5^{\circ} \mathrm{C}$ ) containing ca. $3 \mathrm{l}$ of natural seawater running over a $4 \mathrm{~cm}$ layer of spiked sediments containing $120 \pm 9 \mathrm{kBq}{ }^{65} \mathrm{Zn} \mathrm{g}^{-1}$ and $49 \pm 8 \mathrm{kBq}{ }^{109} \mathrm{Cd}$ $\mathrm{g}^{-1}$ wet wt throughout the experimental period. The depth of the seawater was kept low to minimise movements connected with feeding and to maximise the time of contact with the sediments. All cuttlefish were fed twice daily with Artemia salina and were periodically $\gamma$-counted to follow the radiotracer uptake kinetics. At the end of the experiment, 3 individuals were dissected to determine the distribution of the radiotracers among the digestive gland, cuttlebone and remainder (rest of the organs).

Contamination from seawater: Eggs, juveniles and adults were examined separately, as follows: 
Eggs: The eggs were placed in a $75 \mathrm{l}$ glass aquarium containing natural seawater spiked with ${ }^{65} \mathrm{Zn}(6 \mathrm{kBq}$ $\left.\mathrm{l}^{-1}\right)$ and ${ }^{109} \mathrm{Cd}\left(13 \mathrm{kBq} \mathrm{l}^{-1}\right)$ for $11 \mathrm{~d}$. Spiked activities corresponded to very low additions of stable metals in the seawater, viz. $0.3 \mathrm{pM} \mathrm{Zn}$ and $1.16 \mathrm{pM} \mathrm{Cd}$; this allowed experimentation under simulated conditions that were environmentally realistic.

The spiked seawater was changed daily to maintain radiotracer concentrations relatively constant and to avoid any build-up of exometabolites. During the experiment, activities of the eggs were measured on Days 1, 2, 3, 6, 9, and 11. At each measurement time, 3 eggs were dissected to determine the distribution of the tracers among the capsule membrane, periembryonar liquid and embryo.

Juveniles: Eight newly hatched cuttlefish (mean weight $\pm \mathrm{SD}=0.460 \pm 0.060 \mathrm{~g}$ ) were placed for $36 \mathrm{~h}$ in a $20 \mathrm{l}$ plastic aquarium containing seawater spiked with ${ }^{65} \mathrm{Zn}\left(6 \mathrm{kBq} \mathrm{l}^{-1}\right)$ and ${ }^{109} \mathrm{Cd}\left(13 \mathrm{kBq} \mathrm{l}{ }^{-1}\right)$. After this period, radiolabelled juveniles were held for $29 \mathrm{~d}$ in clean flowing seawater $(75 \mathrm{l}$ glass aquarium, open circuit, $20 \mathrm{l} \mathrm{h}^{-1}$ flow rate, constant aeration, $38 \mathrm{psu}, 16.5 \pm$ $0.5^{\circ} \mathrm{C}$ ). To facilitate the retrieval and counting of each individual during the loss experiment, the juveniles were held individually in the aquaria in separate circular plastic containers $(10 \mathrm{~cm}$ diameter, $5 \mathrm{~cm}$ height) covered with a plastic netting. They were fed twice daily with Artemia sp. and were periodically $\gamma$-counted to follow the radiotracer-loss kinetics. After $29 \mathrm{~d}$ of loss, 4 individuals were dissected to determine the distribution of the tracers among digestive gland, cuttlebone and remainder.

Adults: A group of 5 sexually mature male cuttlefish (mean weight $\pm \mathrm{SD}=253 \pm 97 \mathrm{~g}$ ) was held for $8 \mathrm{~h}$ in a $75 \mathrm{l}$ glass aquarium containing seawater spiked with $20 \mathrm{kBq}$ ${ }^{65} \mathrm{Zn} \mathrm{l}^{-1}$ and $13 \mathrm{kBq}^{109} \mathrm{Cd} \mathrm{l}^{-1}$. In terms of stable metal addition, these activities corresponded to concentrations of $1 \mathrm{pM} \mathrm{Zn}$ and $1.16 \mathrm{pM} \mathrm{Cd}$. Afterwards, the cuttlefish were radioanalysed and transferred to a flowing seawater aquarium (3000 l, open circuit, $600 \mathrm{l} \mathrm{h}^{-1}$ flow rate, constant aeration, $38 \mathrm{psu}, 16.5 \pm 0.5^{\circ} \mathrm{C}$ ) for $6 \mathrm{~d}$. Three adults were dissected after $24 \mathrm{~h}$ and the remainder after $6 \mathrm{~d}$ of depuration. For each individual, the branchial heart appendages, branchial hearts, gills, digestive tract (after removal of the gut contents), genital tract, ink sack, digestive gland, kidneys, mantle skin, mantle muscle, head and cuttlebone were separated, weighed, and their radiotracer content measured.

Contamination through food: To better reflect the different feeding habits of juvenile and adult cuttlefish (Boucher-Rodoni et al. 1987), 2 different prey were selected for the feeding experiments. Mussels (Mytilus galloprovincialis) and brine shrimp (Artemia sp.) were exposed for $7 \mathrm{~d}$ in a plastic aquarium containing $4 \mathrm{l}$ of natural seawater spiked with $6 \mathrm{kBq}{ }^{65} \mathrm{Zn} \mathrm{l}^{-1}$ and
$13 \mathrm{kBq}{ }^{109} \mathrm{Cd} \mathrm{l}^{-1}$. The radiolabelled seawater was changed daily and the organisms were subsequently used as food for cuttlefish.

Juveniles: Eight newly hatched cuttlefish (mean weight $\pm \mathrm{SD}=0.380 \pm 0.030 \mathrm{~g}$ ) were placed in individual plastic containers $(10 \mathrm{~cm}$ diameter, $5 \mathrm{~cm}$ height), and held in a 751 glass aquarium under the same conditions as in the previous experiments. These individuals were then fed for $1 \mathrm{~h}$ with the previously radiolabelled Artemia sp. At the end of the feeding period, each individual was immediately $\gamma$-counted. From that time on, the cuttlefish were fed twice a day with uncontaminated Artemia sp. and regularly $\gamma$-counted to determine radiotracer-loss kinetics and assimilation efficiency. Throughout the depuration period, faeces were removed 3 times per day reduce direct contamination by recycled radiotracers leaching from the faeces. After 29 d, five juveniles were dissected to determine body distribution of the radiotracer.

Adults: Eighteen sexually mature cuttlefish (11 females and 7 males; mean weight $\pm \mathrm{SD}=164 \pm 34 \mathrm{~g}$ and $107 \pm 23 \mathrm{~g}$, respectively) were placed in a $3000 \mathrm{l}$ aquarium under the conditions described above and fed for $2 \mathrm{~h}$ with the soft parts of the previously labelled mussels. Following ingestion, each individual was $\gamma$-counted and the same procedure followed as for the juveniles. In addition, 3 adult cuttlefish were dissected after each radioanalysis to determine the radiotracer content of their different tissues.

Data analyses. Uptake of the radiotracers from seawater and sediments was expressed as change in concentration factors $(\mathrm{CF})$ and transfer factors (TF) (CF and $\mathrm{TF}=\mathrm{Bq} \mathrm{g^{-1 }}$ wet organism divided by the time-integrated Bq $\mathrm{g}^{-1}$ in seawater or sediments, respectively) over time. Uptake kinetics in the eggs were described using a single-component first-order kinetic model:

$$
\mathrm{CF}_{\mathrm{t}}=\mathrm{CF}_{\text {equil }}\left(1-\mathrm{e}^{-k t}\right)
$$

where $\mathrm{CF}_{\mathrm{t}}$ and $\mathrm{CF}_{\text {equil }}$ are concentration factors at Time $t$ (d) and steady state, respectively, and $k$ is the rate constant $\left(\mathrm{d}^{-1}\right)$ (Whicker \& Schultz 1982).

Radiotracer elimination was expressed in terms of percentage of remaining radioactivity, i.e. radioactivity at Time $t$ divided by initial radioactivity measured in the organisms at the beginning of the depuration period. When radiotracer loss plotted against time displayed an exponential shape, the kinetics were described either by single-component exponential model:

$$
A_{t}=A_{0} e^{-\lambda t}
$$

where $A_{t}$ and $A_{0}$ are remaining activities (\%) at Time $t$ (d) and 0 , respectively, and $\lambda$ is the depuration rate constant $\left(\mathrm{d}^{-1}\right)$ which allows the calculation of the radiotracer biological half-life $\left(T_{\mathrm{b} 1 / 2}=\ln 2 / \lambda\right)$, or by a 2 -component exponential model: 

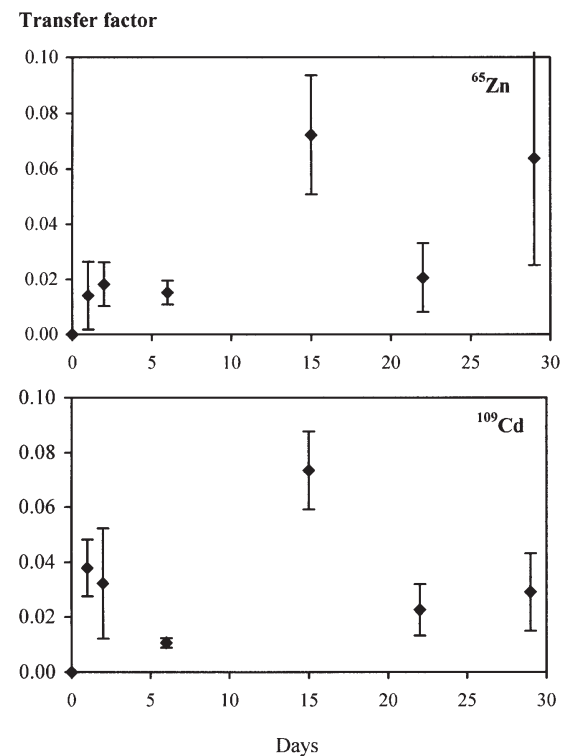

Fig. 1. Sepia officinalis. Transfer factors of ${ }^{65} \mathrm{Zn}$ and ${ }^{109} \mathrm{Cd}$ over time in whole cuttlefish exposed to spiked sediments (mean transfer factor, $\mathrm{TF}_{1} \pm \mathrm{SD}, \mathrm{n}=9$ on Days 0 to 22 , and $\mathrm{n}=3$ on Day 29). (Transfer factor calculated as Bq ${ }^{-1}$ wet wt $\div$ timeintegrated $\mathrm{Bq} \mathrm{^{-1 }}$ sediment)

$$
A_{t}=A_{0_{\mathrm{s}}} \mathrm{e}^{-\lambda_{\mathrm{s}} t}+A_{0_{\mathrm{l}}} \mathrm{e}^{-\lambda_{1} t}
$$

where the s subscript refers to a short-lived component (s component) and the 1 subscript refers to a long-lived component (l component) (Hubbell et al. 1965, Whicker \& Schultz 1982). The exponential model showing the best fit (decision based on calculation of the determination coefficients, $R_{2}$, and examination of the residuals) was then selected.

Constants of the models and their statistics were estimated by iterative adjustment of the model and Hessian matrix computation, respectively, using the nonlinear curve-fitting routines in the Systat 5.2.1 software (Wilkinson 1990). Changes in radiotracer distribution among cuttlefish tissues were tested for significance by the $G$ procedure (adapted from the log-likelihood ratio test) for $2 \times k$ contingency tables (Zar 1996). Changes in percent of radioactivity in a single tissue during the depuration period were tested by 1-way ANOVA (after arcsine transformation of data) followed by the Tukey's multiple comparison test. The significance level for statistical analyses was always set at $\alpha=0.05$.

\section{RESULTS}

\section{Contamination from sediments}

Although cuttlefish spend most of their time on the bottom sediments, very low activities were recorded in the individuals exposed to spiked sediments, even after an exposure as long as $29 \mathrm{~d}$. The transfer factors between sediment and cuttlefish remained $<0.10$ for both ${ }^{65} \mathrm{Zn}$ and ${ }^{109} \mathrm{Cd}$ (Fig. 1). The heterogeneity of the results was substantial and no realistic accumulation kinetics could be calculated for this experiment.

After $29 \mathrm{~d}$, the dissection of 3 individuals showed that the digestive gland contained most of the 2 metals studied, i.e. $75 \pm 8 \%$ for ${ }^{65} \mathrm{Zn}$ and $68 \pm 7 \%$ for ${ }^{109} \mathrm{Cd}$, while the remainder and cuttlebone contained $23 \pm 8$ and $2.5 \pm 0.1 \%$ for ${ }^{65} \mathrm{Zn}$ and $20 \pm 6$ and $11 \pm 1 \%$ for ${ }^{109} \mathrm{Cd}$, respectively.

\section{Contamination from seawater}

\section{Eggs}

The experiment was carried out over $11 \mathrm{~d}$, at the end of which period elevated concentration factors had been reached in the eggs for both ${ }^{65} \mathrm{Zn}(79 \pm 5 \mathrm{SD})$ and
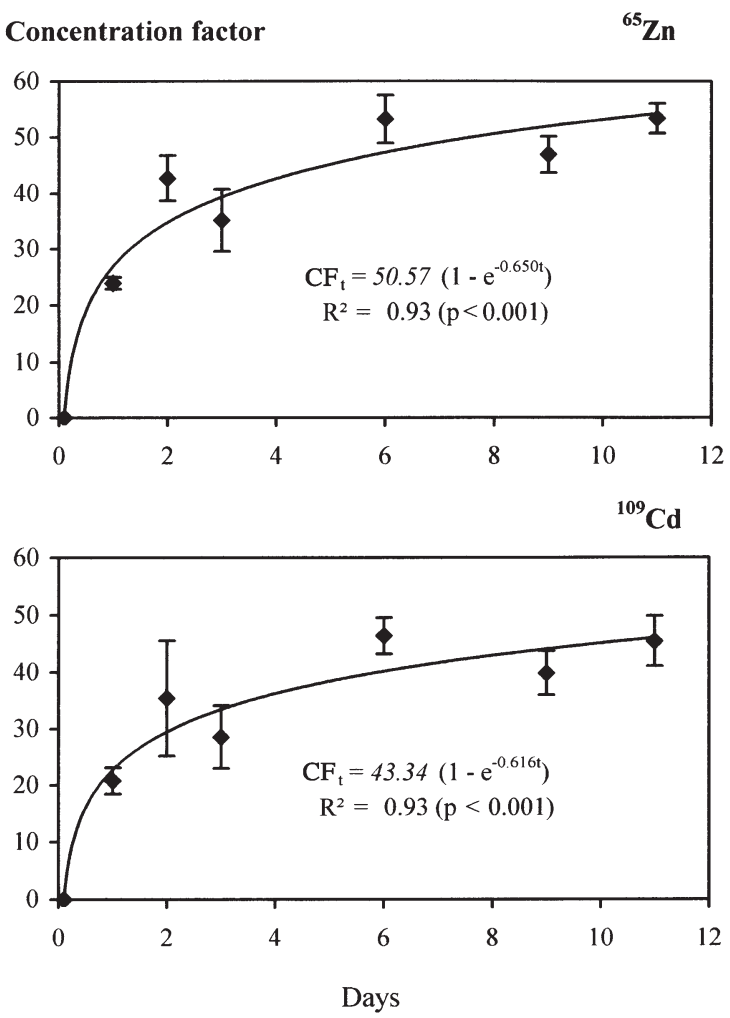

Fig. 2. Sepia officinalis. Uptake of ${ }^{65} \mathrm{Zn}$ and ${ }^{109} \mathrm{Cd}$ in whole eggs exposed for $11 \mathrm{~d}$ to radiotracer in sea water (mean concentration factor, $C F, \pm S D, n=3)$. Fitted model: $\mathrm{CF}_{\mathrm{t}}=\mathrm{CF}_{\text {equil }}$ $\left(1-\mathrm{e}^{-\mathrm{kt}}\right) ; \mathrm{CF}_{\mathrm{t}}, \mathrm{CF}_{\text {equil }}$ : concentration factors at Time $t(\mathrm{~d})$ and steady state, respectively; $k$ : rate constant $\left(\mathrm{d}^{-1}\right) ; \mathrm{R}_{2}$ : determination coefficient; $\mathrm{p}$ : probability of model adjustment. $(\mathrm{CF}=$ $\mathrm{Bq} \mathrm{g}^{-1}$ wet $\mathrm{wt} \div$ time-integrated $\mathrm{Bq} \mathrm{g}^{-1}$ sea water) 
${ }^{109} \mathrm{Cd}(46 \pm 2 \mathrm{SD})$. The uptake of both tracers displayed saturation kinetics (Fig. 2). Most of the radiotracers (96 to $99 \%$ for ${ }^{65} \mathrm{Zn}$ and $99 \%$ for ${ }^{109} \mathrm{Cd}$ ) was always associated with the capsule membrane of the eggs (Fig. 3).

\section{Juveniles and adults}

Due to obvious safety problems resulting from maintenance of cuttlefish in aquaria containing spiked seawater, the exposure time was shortened as much as possible. Preliminary experiments indicated that a $36 \mathrm{~h}$ exposure was necessary for juveniles to achieve activity levels suitable for efficient detection; an $8 \mathrm{~h}$ exposure was found to be sufficient for adults.

Activities ( $\mathrm{Bq} \mathrm{g}{ }^{-1}$ wet wt) recorded in the different cuttlefish tissues after an $8 \mathrm{~h}$ exposure are given in Table 1. In the adults, ${ }^{65} \mathrm{Zn}$ exhibited the highest activities in the skin and gills (121 and $119 \mathrm{~Bq} \mathrm{~g}^{-1}$, respectively) while the branchial hearts contained the highest activities of ${ }^{109} \mathrm{Cd}\left(185 \mathrm{~Bq} \mathrm{~g}{ }^{-1}\right) .{ }^{65} \mathrm{Zn}$ appears to be more bioavailable to cuttlefish than ${ }^{109} \mathrm{Cd}$, since the whole-body CF was 3 times higher for $\mathrm{Zn}$ than for $\mathrm{Cd}$.

The distributions of the radiotracers in body compartments of adult and juvenile cuttlefish are presented in Tables 1 ( 6 d depuration) \& 2 (29 d depuration), respectively. Following exposure, the muscles of adults (i.e. mantle muscle and skin and the head) contained the highest fraction of both radiotracers $(84 \%$ for ${ }^{65} \mathrm{Zn}$ and $62 \%$ for ${ }^{109} \mathrm{Cd}$ ). The digestive gland contained the second highest proportion of ${ }^{109} \mathrm{Cd}$ (i.e. $25 \%$ ). After $6 \mathrm{~d}$ depuration, the global distribution of radiotracers changed, with the fraction of ${ }^{65} \mathrm{Zn}$ increasing significantly in the digestive gland $(p=0.001)$, and
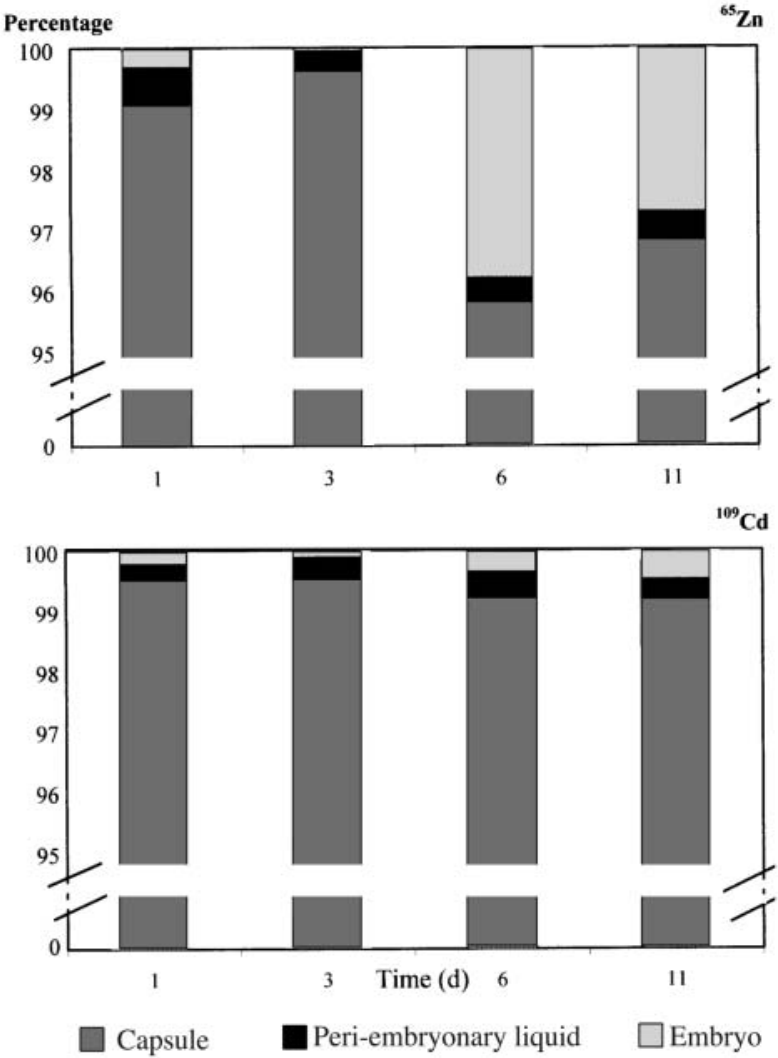

Fig. 3. Sepia officinalis. Radiotracer distribution (mean \%) among the egg compartments at different times during the uptake phase

${ }^{109} \mathrm{Cd}$ in the branchial hearts $(\mathrm{p}=0.004)$ and appendages $(p=0.005)$. In contrast, the tissues in direct contact with seawater generally exhibited a

Table 1. Sepia officinalis. Concentration factor $(\mathrm{CF})$, radiotracer concentrations (mean Bq g ${ }^{-1}$ wet wt \pm SD) and distribution (mean $\% \pm \mathrm{SD})$ in the organs of adult cuttlefish after $8 \mathrm{~h}$ exposure to sea water $(\mathrm{n}=3)$ and after $6 \mathrm{~d}$ depuration $(\mathrm{n}=2)$

\begin{tabular}{|c|c|c|c|c|c|c|c|c|c|c|c|}
\hline \multirow{3}{*}{ Tissue } & \multirow{3}{*}{$\%$ fresh weight } & \multirow{2}{*}{\multicolumn{3}{|c|}{$\left.\overline{\text { Accumulation }}{ }^{65} \mathrm{~h}\right)$}} & \multirow{2}{*}{\multicolumn{2}{|c|}{ Depuration (6 d) }} & \multirow{2}{*}{\multicolumn{3}{|c|}{$\begin{array}{l}{ }^{109} \mathrm{Cd}- \\
\text { Accumulation }(8 \mathrm{~h})\end{array}$}} & \multirow{2}{*}{\multicolumn{2}{|c|}{ Depuration (6 d) }} \\
\hline & & & & & & & & & & & \\
\hline & & $\mathrm{CF}$ & Activity & $\%$ & Activity & $\%$ & $\mathrm{CF}$ & Activity & $\%$ & Activity & $\%$ \\
\hline $\begin{array}{l}\text { Branchial heart } \\
\text { appendages }\end{array}$ & $0.03 \pm 0.004$ & $2.2 \pm 0.6$ & $44 \pm 12$ & $<1$ & 47 & $<1$ & $1.8 \pm 0.8$ & $23 \pm 10$ & $<1$ & 129 & 1 \\
\hline Branchial hearts & $0.10 \pm 0.02$ & $2.8 \pm 0.9$ & $56 \pm 17$ & $<1$ & 44 & $<1$ & $14.2 \pm 8.8$ & $185 \pm 114$ & $2 \pm 2$ & 800 & 13 \\
\hline Gills & $2.3 \pm 0.3$ & $6.0 \pm 2.1$ & $119 \pm 42$ & $7 \pm 0.1$ & 51 & 3 & $1.5 \pm 0.5$ & $20 \pm 7$ & $5 \pm 1$ & 7 & 3 \\
\hline Digestive tract & $2.6 \pm 0.6$ & $1.5 \pm 0.5$ & $30 \pm 9$ & $2 \pm 0.3$ & 26 & 2 & $0.6 \pm 0.3$ & $8 \pm 4$ & $2 \pm 1$ & 4 & 2 \\
\hline Genital tract & $3.6 \pm 1.0$ & $0.9 \pm 0.3$ & $17 \pm 6$ & $2 \pm 0.3$ & 29 & 3 & $0.3 \pm 0.2$ & $4 \pm 2$ & $2 \pm 1$ & 2 & 1 \\
\hline Ink sack & $0.6 \pm 0.2$ & $1.5 \pm 1.1$ & $29 \pm 21$ & $<1$ & 14 & $<1$ & $0.4 \pm 0.2$ & $5 \pm 3$ & $<1$ & 1 & $<1$ \\
\hline Skin & $6.4 \pm 2.1$ & $6.1 \pm 5.3$ & $121 \pm 105$ & $17 \pm 5$ & 50 & 8 & $0.9 \pm 0.7$ & $12 \pm 9$ & $6 \pm 3$ & 5 & 5 \\
\hline Digestive gland & $4.3 \pm 1.2$ & $2.3 \pm 1.8$ & $45 \pm 35$ & $5 \pm 2$ & 536 & 42 & $4.5 \pm 3.8$ & $58 \pm 49$ & $25 \pm 10$ & 91 & 42 \\
\hline Kidney & $0.07 \pm 0.07$ & $3.6 \pm 1.6$ & $72 \pm 31$ & $<1$ & 87 & $<1$ & $1.2 \pm 0.6$ & $16 \pm 8$ & $<1$ & 5 & $<1$ \\
\hline Muscle & $35 \pm 2$ & $1.0 \pm 0.4$ & $20 \pm 8$ & $18 \pm 2$ & 14 & 13 & $0.3 \pm 0.2$ & $4 \pm 2$ & $14 \pm 4$ & 2 & 9 \\
\hline Head & \pm 1 & $2.4 \pm 0.8$ & $48 \pm 16$ & $49 \pm 4$ & 24 & 26 & $0.7 \pm 0.1$ & $9 \pm 1$ & $42 \pm 13$ & 1 & 26 \\
\hline Cuttlebone & $5.1 \pm 0.6$ & $0.1 \pm 0.1$ & $2 \pm 2$ & $<1$ & 8 & 1 & $0.1 \pm 0.0$ & $1 \pm 0$ & $<1$ & $<1$ & $<1$ \\
\hline Whole cephalopod & 100 & $3.8 \pm 1.4$ & $76 \pm 27$ & 100 & 65 & 100 & $1.3 \pm 0.3$ & $17 \pm 4$ & 100 & 13 & 100 \\
\hline
\end{tabular}


Table 2. Sepia officinalis. Radiotracer distribution (mean $\% \pm$ SD) among 3 body compartments of juvenile (J) and adult (A) cuttlefish exposed via sediments, sea water, and food fol-

lowed by $29 \mathrm{~d}$ depuration in uncontaminated sea water

\begin{tabular}{|c|c|c|c|c|}
\hline Experiment & $\mathrm{n}$ & $\begin{array}{l}\text { Digestive } \\
\text { gland }\end{array}$ & $\begin{array}{l}\text { Compartment } \\
\text { Cuttlebone }\end{array}$ & $\mathrm{t} \overline{\text { Remainder }}$ \\
\hline Sediments (J) & 3 & & & \\
\hline${ }^{65} \mathrm{Zn}$ & & $75 \pm 8$ & $3 \pm 0$ & $23 \pm 8$ \\
\hline${ }^{109} \mathrm{Cd}$ & & $68 \pm 7$ & $11 \pm 1$ & $20 \pm 6$ \\
\hline Sea water (J) & 4 & & & \\
\hline${ }^{65} \mathrm{Zn}$ & & $87 \pm 3$ & $0.6 \pm 0.1$ & $13 \pm 3$ \\
\hline${ }^{109} \mathrm{Cd}$ & & $76 \pm 4$ & $1.3 \pm 0.5$ & $23 \pm 4$ \\
\hline Artemia sp. (J) & 5 & & & \\
\hline${ }^{65} \mathrm{Zn}$ & & $82 \pm 2$ & $1.3 \pm 0.9$ & $17 \pm 2$ \\
\hline${ }^{109} \mathrm{Cd}$ & & $91 \pm 3$ & $1.2 \pm 0.9$ & $8 \pm 3$ \\
\hline Mussels (A) & 3 & & & \\
\hline${ }^{65} \mathrm{Zn}$ & & $79 \pm 4$ & $2 \pm 1$ & $19 \pm 2$ \\
\hline${ }^{109} \mathrm{Cd}$ & & $97 \pm 0$ & $<1$ & $3 \pm 0$ \\
\hline
\end{tabular}

lower percentage of radioactivity after $6 \mathrm{~d}$ depuration. This is particularly obvious in the case of ${ }^{65} \mathrm{Zn}$ in the gills $(p<0.001)$ and head ( $p=0.007)$ (see Table 1).

Loss of ${ }^{65} \mathrm{Zn}$ in juvenile cuttlefish followed a singlecomponent exponential model (Fig. 4A, Table 3), with a $T_{\mathrm{b} 1 / 2}$ of ca. 2 mo. In contrast, loss of ${ }^{109} \mathrm{Cd}$ was best described by a 2-component model (Fig. 4B, Table 3). The short-term component was characterised by a very short $T_{\mathrm{b} 1 / 2}(\sim 14 \mathrm{~h})$, while the long-lived loss component which represented a large fraction of the ${ }^{109} \mathrm{Cd}$ content $\left(A_{O_{1}}=71 \%\right)$ turned over with a $T_{\mathrm{b} 1 / 2}$ of ca. $65 \mathrm{~d}$.

After $29 \mathrm{~d}$ in uncontaminated seawater, both tracers were found in highest proportions in the digestive gland of the young cuttlefish (from 76 to $87 \%$ : Table 2 ) and in lowest proportions in the cuttlebone $(\sim 1 \%$ of the total activity).

\section{Contamination through food}

Eighteen adult cuttlefish ingested 123 radiolabelled mussels in $2 \mathrm{~h}$ and 8 juveniles were fed radiolabelled brine shrimp ad libitum for $1 \mathrm{~h}$. The cuttlefish and their prey were immediately $\gamma$-counted for their tracer content (Table 4).

The loss kinetics of ${ }^{65} \mathrm{Zn}$ and ${ }^{109} \mathrm{Cd}$ ingested with food displayed a 2-component exponential model for both juveniles (Fig. 4C, D, Table 3) and adults (Fig. 4E, F, Table 3). For adults, the short-lived component involved about half the total activity in whole cuttlefish (59\% for Zn and $47 \%$ for $\mathrm{Cd}$ ), and both elements had very short $T_{\mathrm{b} 1 / 2_{\mathrm{s}}}$ (ca. $10 \mathrm{~h}$ ) (Table 3). The short-lived loss component represented a smaller fraction of radiotracer (38\% for both elements) for juveniles than for adults (Table 3). The long-lived component of ${ }^{109} \mathrm{Cd}$ depuration had very low depuration rate constants $\left(\lambda_{1}\right)$, which resulted in a very long $T_{\mathrm{b} 1 / 21}$ in both juvenile and adult cuttlefish (>250 d). In contrast, in the young cephalopods, slow depuration rates characterising the long-lived component were noted for ${ }^{65} \mathrm{Zn}\left(T_{\mathrm{b} 1 / 2}=173 \mathrm{~d}\right)$, while in adults, depuration rates were much faster $\left(T_{\mathrm{b} 1 / 2}=38 \mathrm{~d}\right)$. Young individuals incorporated metals more efficiently from brine shrimp (assimilation efficiency, $\mathrm{AE}=63 \%$ for $\mathrm{Zn}$ and $62 \%$ for $\mathrm{Cd}$ ) than did adults ingesting mussels ( $\mathrm{AE}=59 \%$ for $\mathrm{Zn}$ and $47 \%$ for Cd) (Table 3 ).

The distribution of radioactivity in cuttlefish tissues was determined on several occasions for adults (Table 5), but only at the end of the loss period for juveniles (Table 2). At the end of the depuration period, the highest proportion of radiotracer was found in the digestive gland (i.e. 79 and $97 \%$ in adults and 82 and $91 \%$ in juveniles for ${ }^{65} \mathrm{Zn}$ and ${ }^{109} \mathrm{Cd}$, respectively). In adults, tissue distribution of ${ }^{65} \mathrm{Zn}$ varied significantly during the experiment (G-test, $\mathrm{p}<0.05)$ (Table 5). The proportion of ${ }^{65} \mathrm{Zn}$ activity decreased in the muscular

Table 3. Sepia officinalis. Parameters of the equations describing the loss kinetics of ${ }^{65} \mathrm{Zn}$ and ${ }^{109} \mathrm{Cd}$ in whole cuttlefish previously exposed through different pathways: (1) juveniles previously exposed for $36 \mathrm{~h}$ to radiotracers in sea water; (2) juveniles fed labelled brine shrimp Artemia sp.; (3) adults that received a single ration of labelled mussels Mytilus galloprovincialis. $\mathrm{O}, \mathrm{T}$ : 1- and 2-component loss models, respectively; ASE: asymptotic standard error; $\mathrm{R}^{2}$ : determination coefficient; $\mathrm{p}$ : probability of model adjustment. See 'Materials and methods_Data analyses' for other abbreviations and for calculations

\begin{tabular}{|c|c|c|c|c|c|c|c|c|c|}
\hline Pathway & Model & $A_{O_{S}}(\mathrm{ASE})$ & Is (ASE) & $T_{\mathrm{b} 1 / 2} \mathrm{~s}$ & $A_{O_{1}}(\mathrm{ASE})$ & $\lambda /(\mathrm{ASE})$ & $T_{\mathrm{b} 1 / 2 \mathrm{l}}$ & $\mathrm{R}^{2}$ & $\mathrm{p}$ \\
\hline \multicolumn{10}{|c|}{ (1) Sea water exposure } \\
\hline${ }^{65} \mathrm{Zn}$ & $\mathrm{O}$ & $92.5(2.0)$ & $0.013(0.002)$ & 53 & - & - & - & 0.98 & $<0.001$ \\
\hline${ }^{109} \mathrm{Cd}$ & $\mathrm{T}$ & $29.2(6.7)$ & $1.131(0.530)$ & 0.6 & $71.4(4.2)$ & $0.011(0.005)$ & 65 & 0.96 & $<0.001$ \\
\hline \multicolumn{10}{|c|}{ (2) Labelled brine shrimp exposure } \\
\hline${ }^{65} \mathrm{Zn}$ & $\mathrm{T}$ & $37.5(3.9)$ & $1.044(0.232)$ & 0.7 & $63.2(2.3)$ & $0.004(0.003)$ & 173.3 & 0.98 & $<0.001$ \\
\hline${ }^{109} \mathrm{Cd}$ & $\mathrm{T}$ & $37.8(6.3)$ & $0.653(0.223)$ & 1.1 & $62.3(4.4)$ & $0.003(0.004)$ & 256.7 & 0.96 & $<0.001$ \\
\hline \multicolumn{10}{|c|}{ (3) Labelled mussel exposure } \\
\hline${ }^{65} \mathrm{Zn}$ & $\mathrm{T}$ & $59.1(4.2)$ & $1.940(0.545)$ & 0.36 & $40.9(3.0)$ & $0.018(0.007)$ & 38 & 0.95 & $<0.001$ \\
\hline${ }^{109} \mathrm{Cd}$ & $\mathrm{T}$ & $46.7(6.5)$ & $1.509(0.817)$ & 0.46 & $53.1(4.6)$ & $-0.010(0.006)$ & $\infty$ & 0.91 & $<0.001$ \\
\hline
\end{tabular}


Fig. 4. Sepia officinalis. (A, B) Loss of ${ }^{65} \mathrm{Zn}$ and ${ }^{109} \mathrm{Cd}$ in whole juvenile cuttlefish previously exposed to radiolabelled sea water for $36 \mathrm{~h}$ (mean remaining activity \pm $\mathrm{SD}, \mathrm{n}=8$ on Day 0 and $\mathrm{n}=4$ on Day 29); (C, D) loss of ${ }^{65} \mathrm{Zn}$ and ${ }^{109} \mathrm{Cd}$ in whole juvenile cuttlefish previously fed radiolabelled Artemia sp. (mean remaining activity $\pm \mathrm{SD}, \mathrm{n}=8$ on Day 0 and $n=5$ on Day 29); (E, F) loss of ${ }^{65} \mathrm{Zn}$ and ${ }^{109} \mathrm{Cd}$ in whole adult cuttlefish previously fed radiolabelled mussels (mean remaining activity $\pm \mathrm{SD}, \mathrm{n}=18$ on Day 0 and $n=3$ on Day 29). Parameters of equations given in Table 3
Remaining activity (\%)

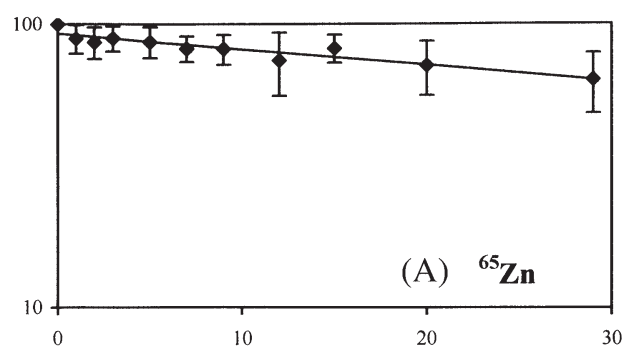

Remaining activity (\%)

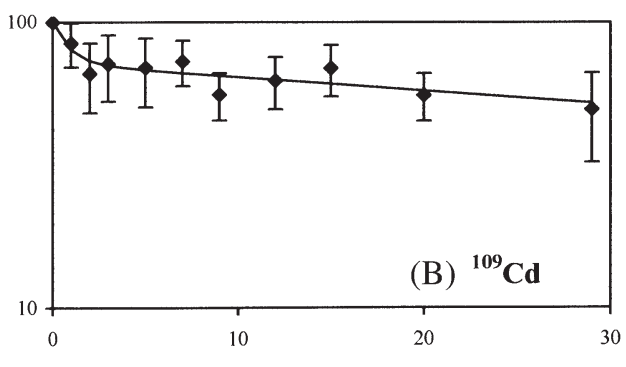

Juveniles exposed via sea water
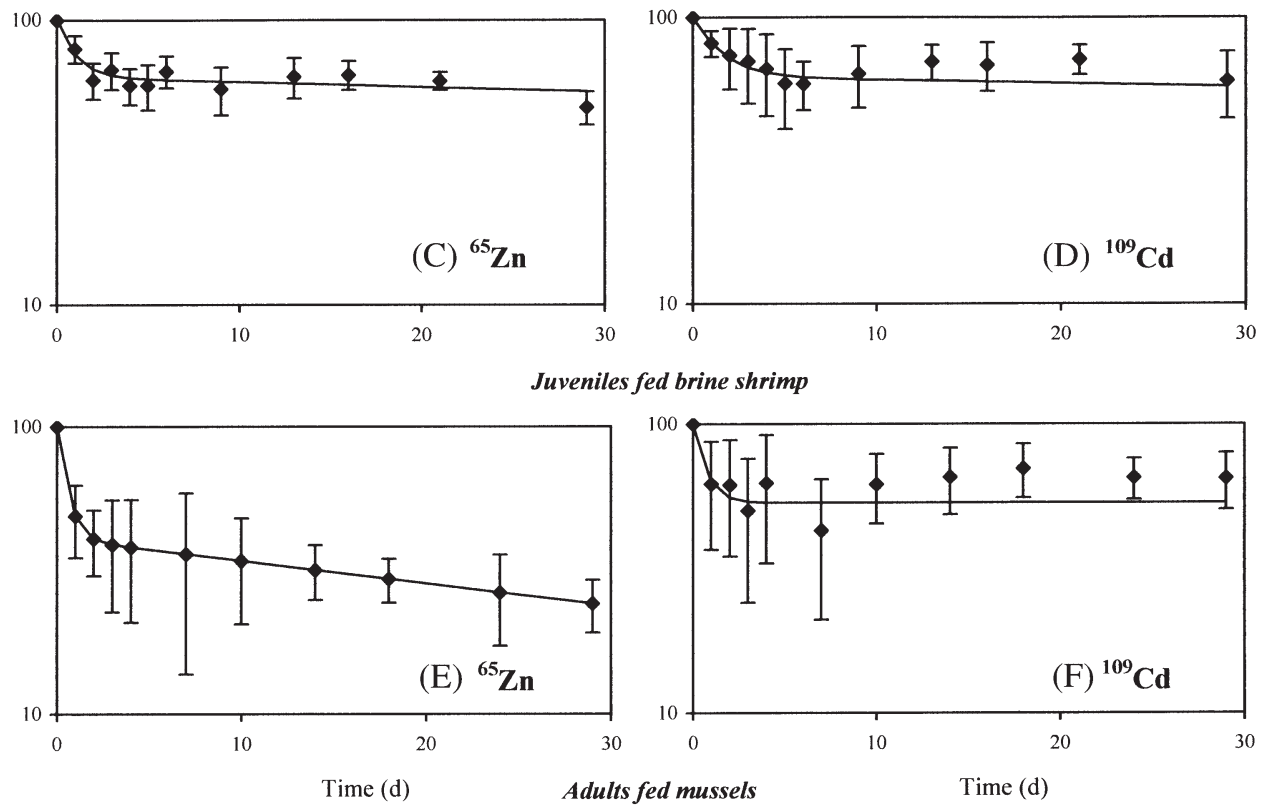

tissues (mantle muscle and cephalic parts) and increased in the digestive gland (Tukey test, $p=0.021$ ), suggesting a lower depuration rate in the digestive gland than in other organs (Table 5). For ${ }^{109} \mathrm{Cd}$, a G-test did not indicate any significant difference among radioactivity distributions during the experiment.

\section{DISCUSSION}

The use of radiotracers in very low concentrations allows the investigation of trace metal metabolism at environmentally realistic conditions. Furthermore,

these radiotracer experiments permit the simultaneous investigation of several elements without interelement interferences.

During embryonic development, Zn and Cd were efficiently taken up from seawater by the eggs, with a $\mathrm{CF}$ of 79 for ${ }^{65} \mathrm{Zn}$ and 46 for ${ }^{109} \mathrm{Cd}$ after only $11 \mathrm{~d}$ exposure. However, most of the radiotracers was associated with the capsule membrane of the egg, which thus would act as an efficient shield protecting the embryo against direct metal exposure. This observation is surprising for $\mathrm{Zn}$, since it is an element essential for the development of the embryos. This may in fact explain the large amounts of this metal occurring in cephalo-

Table 4. Radioactivity (mean $\pm \mathrm{SD})$ in Mytilus galloprovincialis soft parts $(\mathrm{n}=20)$ and in Artemia sp. $(\mathrm{n}=10)$ used as radiolabelled food for adult and juvenile Sepia officinalis , respectively, and radioactivity (Bq, range) in both groups of $S$. officinalis fed these prey

\begin{tabular}{|lcccc|}
\hline Radiotracer & $\begin{array}{c}\text { M. galloprovincialis } \\
(\mathrm{n}=20)\left(\mathrm{Bq} \mathrm{g}^{-1} \text { wet } \mathrm{wt}\right)\end{array}$ & $\begin{array}{c}\text { S. officinalis } \\
(\mathrm{n}=18 \text { adults })(\mathrm{Bq})\end{array}$ & $\begin{array}{c}\text { Artemia sp. } \\
\text { Bq ind. }^{-1}(\mathrm{n}=10)\end{array}$ & $\begin{array}{c}\text { S. officinalis } \\
(\mathrm{n}=8 \text { juveniles) }(\mathrm{Bq})\end{array}$ \\
\hline${ }^{65} \mathrm{Zn}$ & $780 \pm 129$ & $249-4284$ & $10.92 \pm 0.32$ & $30-98$ \\
${ }^{109} \mathrm{Cd}$ & $996 \pm 162$ & $117-4126$ & $7.19 \pm 0.37$ & $19-68$ \\
\hline
\end{tabular}


Table 5. Sepia officinalis. Radiotracer distribution (mean $\% \pm \mathrm{SD}, \mathrm{n}=3$ ) among the tissues and organs of adult cuttlefish exposed to the radiotracers through food, after 3 different periods of depuration in uncontaminated sea water

\begin{tabular}{|c|c|c|c|c|c|c|}
\hline \multirow{2}{*}{ Tissues } & \multicolumn{2}{|c|}{$1 \mathrm{~d}$} & \multicolumn{2}{|c|}{$18 \mathrm{~d}$} & \multicolumn{2}{|c|}{$29 \mathrm{~d}$} \\
\hline & ${ }^{65} \mathrm{Zn}$ & ${ }^{109} \mathrm{Cd}$ & ${ }^{65} \mathrm{Zn}$ & ${ }^{109} \mathrm{Cd}$ & ${ }^{65} \mathrm{Zn}$ & ${ }^{109} \mathrm{Cd}$ \\
\hline Branchial heart appendages & $<1$ & $<1$ & $<1$ & $<1$ & $<1$ & $<1$ \\
\hline Branchial heart & $<1$ & $1 \pm 0$ & $<1$ & $<1$ & $<1$ & $<1$ \\
\hline Gill & $3 \pm 0$ & $<1$ & $1 \pm 0$ & $<1$ & $1 \pm 0$ & $<1$ \\
\hline Digestive tract & $4 \pm 1$ & $3 \pm 1$ & $2 \pm 0$ & $2 \pm 0$ & $2 \pm 0$ & $2 \pm 0$ \\
\hline Genital tract & $3 \pm 0$ & $<1$ & $2 \pm 0$ & $<1$ & $2 \pm 0$ & $<1$ \\
\hline Ink sack & $<1$ & $<1$ & $4 \pm 2$ & $<1$ & $5 \pm 0$ & $<1$ \\
\hline Skin & $4 \pm 1$ & $<1$ & $1 \pm 0$ & $<1$ & $1 \pm 0$ & $<1$ \\
\hline Digestive gland & $45 \pm 6$ & $92 \pm 2$ & $74 \pm 5$ & $97 \pm 1$ & $79 \pm 4$ & $97 \pm 0$ \\
\hline Kidney & $<1$ & $<1$ & $<1$ & $<1$ & $<1$ & $<1$ \\
\hline Muscle & $16 \pm 1$ & $1 \pm 0$ & $6 \pm 1$ & $<1$ & $4 \pm 0$ & $<1$ \\
\hline Head & $22 \pm 5$ & $2 \pm 0$ & $11 \pm 3$ & $1 \pm 0$ & $7 \pm 1$ & $1 \pm 0$ \\
\hline Cuttlebone & $1 \pm 0$ & $<1$ & $1 \pm 0$ & $<1$ & $2 \pm 1$ & $<1$ \\
\hline
\end{tabular}

pod ovaries, such as in the squid Illex argentinus in which the female gonad may account for $13.6 \%$ of the total Zn body burden (Gerpe et al. 2000). This suggests that eggs contain enough $\mathrm{Zn}$ for the needs of the embryo, and that additional metal could become toxic for the embryo. In fact, Zn incorporation may also be blocked to inhibit $\mathrm{Cd}$ from crossing the capsule membrane, since the latter element has chemical properties similar to Zn and follows the same uptake pathways. Nevertheless, the exact mechanism causing the specific blockage of both metals in the capsule membrane of the eggs remains unknown.

Although the experimental contamination via seawater was only carried out for a short period of time, the activities recorded in the whole cuttlefish suggest that they would efficiently accumulate these 2 elements directly from water. In other invertebrates such as echinoderms or bivalves, the major fraction of the radiotracers was found in the calcified parts, i.e. the body wall of sea urchins (Warnau et al. 1996) and the shell of mussels (Guary 1980, Fisher et al. 1996). Although the cuttlefish Sepia officinalis has a calcareous compartment (the cuttlebone) representing ca. $5 \%$ of the total body weight, this contained $<1 \%$ of the total radioactivity of ${ }^{65} \mathrm{Zn}$ and ${ }^{109} \mathrm{Cd}$ after seawater exposure. This may be due to the internal location of the cuttlebone, which has no direct contact with ambient seawater. Thus, trace elements are distributed more homogeneously among cuttlefish tissues than in invertebrates with calcareous compartments directly in contact with seawater (bivalves) or protected by a thin epidermis (sea urchins). In $S$. officinalis, most of the tracers taken up, i.e. $84 \%$ for ${ }^{65} \mathrm{Zn}$ and $62 \%$ for ${ }^{109} \mathrm{Cd}$, were located in the tissues in direct contact with seawater, i.e. mantle, skin of the mantle, and head.

If direct sorption of metals onto the cuttlebone is not possible (it is entirely surrounded by muscular tissue), transfer and redistribution of $\mathrm{Cd}$ to this compartment would be expected, since the cuttlebone is mainly composed of calcium carbonate. Indeed, Cd mimics Ca because of their similar ionic radius (Huheey 1983). Therefore, due to its mineral composition, the cuttlebone of Sepia officinalis could play a storage role for some elements, including $\mathrm{Cd}$. However, the results presented here showed that transfer of radiotracers to the cuttlebone were very limited (even after a long depuration period) following either seawater or food exposure (Tables $2 \& 5$ ).

After $6 \mathrm{~d}$ in uncontaminated seawater, the 2 elements were found to be distributed differently among body compartments (Table 1). This allowed the determination of 3 distinct groups of tissues: (1) those in which the percentage of total radioactivity had decreased (muscular parts and gills); (2) those in which there was an increase in the percentage of total radioactivity (i.e. digestive gland, branchial hearts and appendages); and (3) those in which the percentage of the radioactivity remained similar (cuttlebone, kidney, ink sack, genital tract and gut). The tissues of the first group might have rapid depuration rates, while those of the second group (which are also known or supposed detoxification organs: Mangold et al. 1989) would have either a longer retention capacity or would be the targets of preferential translocation of the elements from other organs. A similar distinction for the tissues has been made for the squid Sepioteuthis lessoniana exposed to stable Cd in seawater (Koyama et al. 2000); in that study, the concentration of $\mathrm{Cd}$ in the digestive gland was still increasing several $d$ after the beginning of depuration, while loss was immediate in the gills and mantle. Koyama et al. suggested a stronger retention of the metal in the digestive gland than in other organs. Nevertheless, our results clearly demonstrated (1) the translocation of $\mathrm{Zn}$ to the diges- 
tive gland, where the activity was more than 10 times higher after 6d depuration, and (2) the translocation of $\mathrm{Cd}$ to the branchial hearts and appendages, in which activities increased by a factor of 5 and 4 , respectively, over the same period of time (see Table 1).

After bioaccumulation from seawater, $\mathrm{Zn}$ and $\mathrm{Cd}$ were released from juvenile cuttlefish following a single component $\left({ }^{65} \mathrm{Zn}\right)$ or a 2 -component $\left({ }^{109} \mathrm{Cd}\right)$ exponential loss kinetics. Whole body loss was relatively slow for both ${ }^{65} \mathrm{Zn}$ and ${ }^{109} \mathrm{Cd}$, with mean biological half-lives of 53 and $65 \mathrm{~d}$, respectively. Our results are quite similar to those obtained for $\mathrm{Zn}$ in the octopus Octopus vulgaris, which displayed a mean half-life of $74 \mathrm{~d}$ (Ueda et al. 1985). Comparison for ${ }^{109} \mathrm{Cd}$ retention with other cephalopod species is not possible as there are apparently no data available in the literature. However, similar half-lives for ${ }^{109} \mathrm{Cd}$ have been reported for other mollusc species such as the mussels Mytilus edulis (67 to 78 d) and M. galloprovincialis (16 to 60 d) (Fisher et al. 1996, Wang et al. 1996). For these bivalves, the dissolved phase is usually considered a significant source of metal accumulation (Nolan \& Dahlgaard 1991, Wang et al. 1996), since they have high filtration rates and can process large volumes of seawater. As the respiration rates of cephalopods are lower than the filtration rates of bivalves, the dissolved phase might be of less importance for metal uptake in cephalopods than it is in bivalves.

After $29 \mathrm{~d}$ depuration, the residual radioactivity was mainly located in the digestive gland. Thus, the digestive gland appears to be the major storage organ for both $\mathrm{Zn}$ and $\mathrm{Cd}$. It is also noteworthy that ${ }^{109} \mathrm{Cd}$ activities in branchial hearts were relatively elevated following exposure to contaminated seawater (Table 1). After $6 \mathrm{~d}$ loss, branchial hearts and appendages exhibited a significantly higher percentage of total ${ }^{109} \mathrm{Cd}$ than at Day 0. In fact, the branchial hearts of cephalopods generally contain very low $\mathrm{Cd}$ concentrations (Miramand \& Guary 1980, Miramand \& Bentley 1992), even though they concentrate many elements such as copper, iron, cobalt, nickel or vanadium (Nakahara et al. 1979, Ueda et al. 1979, Miramand \& Guary 1980, Miramand \& Bentley 1992). Radiotracer investigations of Octopus vulgaris have also shown the ability of this octopus to concentrate radionuclides such as americium and plutonium in their branchial hearts and appendages (Guary et al. 1981, Guary \& Fowler 1982). Furthermore, ${ }^{241} \mathrm{Am}$ is eliminated only very slowly from octopus tissues (Guary \& Fowler 1982). In contrast, Cd has a very short retention time in branchial hearts in cephalopods, which probably serve as excretory organs for this element. In fact, these organs have circulatory and excretory functions, since they are actively involved in the ultrafiltration of the haemolymph (Mangold et al. 1989). Accordingly, Cd that is directly taken up in the cephalopod haemolymph through the gills could be excreted by these organs.

Following the dietary contamination of young and adult cuttlefish, loss kinetics were described by a 2component exponential model. The $T_{\mathrm{b} 1 / 2_{\mathrm{S}}}$ of the elements were very short $(\leq 1 \mathrm{~d})$. In this case, the shortlived component would represent the unabsorbed fraction of the element which was directly eliminated with the faeces. Indeed, this loss rate corresponds quite well to the gut-residence time in both juvenile and adult Sepia officinalis, in which digestion is typically completed in ca. $15 \mathrm{~h}$ at $20^{\circ} \mathrm{C}$ (Boucaud-Camou 1973). Thus, the remaining radioactivity can be considered to be the absorbed fraction of the ingested dose. In adults, $41 \%$ of ${ }^{65} \mathrm{Zn}$ and $53 \%$ of ${ }^{109} \mathrm{Cd}$ from ingested mussels were readily incorporated into the tissues. These elements were absorbed to an even greater degree in juvenile cuttlefish, with assimilation efficiencies (AE) of $63 \%$ for ${ }^{65} \mathrm{Zn}$ and $62 \%$ for ${ }^{109} \mathrm{Cd}$ from ingested brine shrimp. These differences between juveniles and adults could be due to differences in efficiency of their digestive metabolism (Mangold 1989). However, since food type was different in the experiments with juveniles (fed brine shrimp Artemia sp.) and adults (fed mussels Mytilus edulis), it is difficult to determine whether the differences in elementary AE are due to different energetic needs of juvenile and adult cuttlefish or to differences in element bioavailability. Indeed, different storage and/or detoxification processes in mussels and brine shrimps could partially control metal bioavailability owing to the different physico-chemical speciation of the elements in the prey. In general, metals located in the soluble subcellular fraction (i.e. cytosol) are more bioavailable to higher trophic levels, whereas those bound to the insoluble subcellular fraction have a lower potential for transfer to predators (Reinfelder \& Fisher 1991, Wallace \& Lopez 1997). Likewise, it would be of interest to examine trace element assimilation efficiencies in cephalopods with respect to the subcellular location of the elements in each prey.

The biological half-life of ${ }^{65} \mathrm{Zn}$ was longer in juveniles than in adults, probably because the newly hatched cuttlefish incorporate large amounts of $\mathrm{Zn}$ in their cells to meet their metabolic needs. In this context, it was also expected that ${ }^{109} \mathrm{Cd}$ would have been retained more efficiently $\left(T_{\mathrm{b} 1 / 2}=257 \mathrm{~d}\right)$ than an essential element such as Zn. Cd was also strongly retained in the tissues of adults, with an estimated $T_{\mathrm{b} 1 / 2}$ tending towards infinity. These very elevated retention capacities concerned almost exclusively the digestive gland. Indeed, the digestive gland retained 91 and $97 \%$ of the total body burden of ${ }^{109} \mathrm{Cd}$ in juvenile and adult cuttlefish, respectively. Thus, assimilated $\mathrm{Cd}$ that is contained in the digestive gland may be considered as actually stored. The occurrence of $\mathrm{Cd} T_{\mathrm{b} 1 / 2}$ of the same 
time-scale order as the cuttlefish lifespan (1 to 2 yr in the Mediterranean: von Boletzky 1983) suggests that during their evolution cephalopods have developed a detoxification strategy favouring the storage of this toxic element instead of its elimination.

The high degree of $\mathrm{Cd}$ retention might thus be a result of a very efficient detoxification system which allows this toxic metal to be stored in a nontoxic form. Such a detoxification process could involve precipitation or co-precipitation of metals into metal-rich granules leading to a highly stable form. This sequestering process has been observed for heavy metals in several invertebrate species (Coombs \& George 1978, Brown 1982, Taylor \& Simkiss 1984). However, in cephalopods, subcellular investigations have shown that $\mathrm{Cd}$ is mainly associated with soluble (cytosolic) compounds, but that this proportion decreases when the concentration of total $\mathrm{Cd}$ increases in the organ (Bustamante et al. 2002). This is mainly due to the transfer and sequestration of $\mathrm{Cd}$ in the lysosomal system, which is very well developed in cephalopods. Nevertheless, neither ultrastructural nor microanalytical investigations have shown the presence of any granules in the digestive gland of squids or cuttlefish (Boucaud-Camou \& Boucher-Rodoni 1983, Bustamante 1998).

$\mathrm{Cd}$ analyses of the digestive gland of adult cuttlefish which died during collection or acclimation period revealed Cd concentrations $\left(18.6 \pm 7.3 \mu \mathrm{g} \mathrm{g}^{-1}\right.$ dry wt) similar to those measured in the same species from the Bay of Biscay $\left(9.4 \pm 4.1 \mu \mathrm{g} \mathrm{g}^{-1}\right.$ dry wt: Bustamante 1998) and the English Channel $\left(12.9 \pm 0.3 \mu \mathrm{g} \mathrm{g}^{-1}\right.$ dry wt: Miramand \& Bentley 1992). Given that $64 \%$ of the total Cd in the digestive gland of Sepia officinalis from the Bay of Biscay were located in the soluble fraction of this organ (Bustamante et al. 2002), it is most likely that the accumulated ${ }^{109} \mathrm{Cd}$ was mainly bound to soluble compounds in the cuttlefish used in our experiments. Such an efficient detoxification system could involve cytosolic proteins such as metallothioneins as suggested by the chromatographic results obtained with different squid species (Tanaka et al. 1983, Finger \& Smith 1987, Castillo \& Maita 1991), but proteins with a high molecular weight ( $\geq 70 \mathrm{kDa}$ ) may play an important role in Cd detoxification, allowing cephalopods to accumulate high Cd levels (Tanaka et al. 1983, Finger \& Smith 1987, Castillo \& Maita 1991). The lower retention efficiency for Cd noted in juvenile cuttlefish (257 d vs infinity in adults) would result from the incomplete development of the digestive gland in early juveniles. Indeed the digestive gland is not yet fully grown (and thus not yet fully physiologically active) in juveniles, since its 2 segments are still separated by the anterior lobe of the inner yolk sack (Boucher-Rodoni et al. 1987). Interestingly, the structure of the digestive gland in juveniles appears to be similar to that of adults
$30 \mathrm{~d}$ after hatching, and it becomes functional as soon as the cuttlefish begins to feed (i.e. 1 to $2 \mathrm{~d}$ after hatching). Thus, it would be of particular interest to compare the detoxification processes of $\mathrm{Cd}$ by cytosolic proteins in both juvenile and adult cephalopods.

In contrast to most marine invertebrates, which accumulate Cd mainly from seawater (Dahlgaard 1981, Nolan \& Dahlgaard 1991, Fisher et al. 1996, Warnau et al. 1996), cephalopods such as Sepia officinalis accumulate Cd principally from food. Once incorporated, the fate of this metal is mainly controlled by the digestive gland, which acts as an efficient detoxification organ whatever the source of Cd (seawater, food, or sediment). This detoxification process occurs throughout the lifetime of the cephalopod, except during embryonic development. Results for Zn were very similar to those for $\mathrm{Cd}$ in juveniles contaminated through seawater and through food. However, a lower retention $\mathrm{Zn}$ in adults could be a result of displacement of this element from the cytosolic proteins in the digestive gland by other metals such as Cd.

Acknowledgements. We thank Dr S. von Boletzky from the Marine Station of Banyuls (France) for providing us with some of the cuttlefish eggs, N. Tevenin and P. Gilles from the Musée Océanographique (Monaco) for supplying adult cuttlefish, and Professor E. Boucaud-Camou for advice on rearing cuttlefish. M. W. is an Honorary Research Associate of the National Fund for Scientific Research (NFSR, Belgium). The Marine Environment Laboratory operates under a bipartite agreement between the International Atomic Energy Agency and the Government of the Principality of Monaco.

\section{LITERATURE CITED}

Boletzky S von (1983) Sepia officinalis. In: Boyle PR (ed) Cephalopod life cycles, Vol 1. Species accounts. Academic Press, London, p 31-52

Boucaud-Camou E (1973) Etude de l'appareil digestif de Sepia officinalis L. (Mollusque Céphalopode). Essai d'analyse expérimentale des phénomènes digestifs. $\mathrm{PhD}$ thesis, University of Caen, France

Boucaud-Camou E, Boucher-Rodoni R (1983) Feeding and digestion in cephalopods. In: Saleuddin ASM, Wilbur KM (eds) The Mollusca, Vol 5. Physiology, Part 2. Academic Press, New York, London, p 149-187

Boucher-Rodoni R, Boucaud-Camou E, Mangold K (1987) Feeding and digestion. In: Boyle PR (ed) Cephalopod life cycles. Vol II. Comparative reviews. Academic Press, New York, London, p 85-108

Brown BE (1982) The form and function of metal-containing 'granules' in invertebrate tissues. Biol Rev Camb Philos Soc 57:621-667

Bustamante P (1998) Etude des processus de bioaccumulation et de détoxication d'éléments traces (métaux lourds et terres rares) chez les mollusques céphalopodes et bivalves pectinidés. Implication de leur biodisponibilité pour le transfert vers les prédateurs. PhD thesis, University of La Rochelle, France

Bustamante P, Cherel Y, Caurant F, Miramand P (1998a) 
Cadmium, copper and zinc in octopuses from Kerguelen Islands, southern Indian Ocean. Polar Biol 19:264-271

Bustamante P, Caurant F, Fowler SW, Miramand P (1998b) Cephalopods as a vector for the transfer of cadmium to top marine predators in the north-east Atlantic Ocean. Sci Total Environ 220:71-80

Bustamante P, Grigioni S, Boucher-Rodoni R, Caurant F, Miramand P (2000) Bioaccumulation of 12 trace elements in the tissues of the nautilus Nautilus macromphalus from New Caledonia. Mar Pollut Bull 40(8):688-696

Bustamante P, Cosson RP, Gallien I, Caurant F, Miramand P (2002) Cadmium detoxification processes in the digestive gland of cephalopods in relation to accumulated cadmium concentrations. Mar Environ Res 53:227-241

Castillo LV, Maita Y (1991) Isolation and partial characterisation of cadmium binding proteins from the oceanic squid, Ommastrephes bartrami. Bull Fac Fish Hokkaido Univ 42: 26-34

Clarke MR (1996) Cephalopods as prey. III. Cetaceans. Philos Trans R Soc Lond Ser B 351:1053-1065

Coombs TL, George SG (1978) Mechanisms of immobilisation and detoxification of metals in marine organisms. In: Mclusky DS, Berry AJ (eds) Physiology and behaviour of marine organisms. Pergamon Press, New York, p 179-187

Croxall JP, Prince PA (1996) Cephalopods as prey. I. Seabirds. Philos Trans R Soc Lond Ser B 351:1023-1043

Dahlgaard H (1981) Bioindicators for monitoring radioactive pollution of the marine environment-experiments on the feasibility of Mytilus as a bioindicator in estuarine environments with some comparisons to Fucus. Res Establ Risø Rep 15

Finger JM, Smith JD (1987) Molecular association of $\mathrm{Cu}$, Zn, $\mathrm{Cd}$ and ${ }^{210} \mathrm{Po}$ in the digestive gland of the squid Nototodarus gouldi. Mar Biol 95:87-91

Fisher NS, Nolan CV, Fowler SW (1991) Scavenging and retention of metals by zooplankton fecal pellets and marine snow. Deep-Sea Res 38:1261-1275

Fisher NS, Teyssié JL, Fowler SW, Wang WX (1996) Accumulation and retention of metals in mussels from food and water: a comparison under field and laboratory conditions. Environ Sci Technol 30:3232-3242

Gerpe MS, de Moreno JEA, Moreno VJ, Patat ML (2000) Cadmium, zinc and copper accumulation in the squid Illex argentinus from the southwest Atlantic Ocean. Mar Biol 136:1039-1044

Gonzalez AF, Guerra A, Pascual S, Briand P (1998) Vulcanoctopus hydrothermalis gen. et sp. nov. (Mollusca, Cephalopoda): an octopod from a deep-sea hydrothermal vent site. Cah Biol Mar 39:169-184

Guary JC (1980) Recherches sur les transferts et la fixation du plutonium, de l'américium et du neptunium dans le milieu marin. PhD thesis, University of Aix-Marseille II, France

Guary JC, Fowler SW (1982) Experimental studies on the biokinetics of plutonium and americium in the cephalopod Octopus vulgaris. Mar Ecol Prog Ser 7:327-335

Guary JC, Higgo JJW, Cherry RD, Heyraud M (1981) High concentrations of transuranic and natural radioactive elements in the branchial hearts of the cephalopods Octopus vulgaris. Mar Ecol Prog Ser 4:123-126

Hubbell SP, Sikora A, Paris OH (1965) Radiotracer, gravimetric and calorimetric studies of ingestion and assimilation rates of an isopod. Health Phys 11:1485-1501

Huheey JE (1983) Inorganic chemistry, 3rd edn. Harper International, Cambridge

Editorial responsibility: Otto Kinne (Editor),

Oldendorf/Luhe, Germany
Koyama J, Nanamori N, Segawa S (2000) Bioaccumulation of waterborne and dietary cadmium by oval squid Sepioteuthis lessoniana, and its distribution among organs. Mar Pollut Bull 40:961-967

Mangold K (1989) Reproduction, croissance et durée de vie. In: Grassé PP (ed) Traité de Zoologie, Vol 5. Mangold K (ed) Céphalopodes. Masson Cie, Paris, p 493-552

Mangold K, Bidder AM, Boletzky SV (1989) Appareils excréteurs et excrétion. In: Grassé PP (ed) Traité de Zoologie, Vol 5. Mangold K (ed) Céphalopodes. Masson Cie, Paris, p 437-457

Martin JH, Flegal AR (1975) High copper concentrations in squid livers in association with elevated levels of silver, cadmium, and zinc. Mar Biol 30:51-55

Miramand P, Bentley D (1992) Concentration and distribution of heavy metals in tissues of two cephalopods, Eledone cirrhosa and Sepia officinalis, from the French coast of the English Channel. Mar Biol 114:407-414

Miramand P, Guary JC (1980) High concentrations of some heavy metals in tissues of the Mediterranean octopus. Bull Environ Contam Toxicol 24:783-788

Nakahara M, Koyanagi T, Ueda T, Shimizu C (1979) Peculiar accumulation of cobalt-60 by the branchial hearts of octopus. Bull Jpn Soc Scient Fish 45:539

Nieboer E, Richardson DHS (1980) The replacement of the nondescript term 'heavy metal' by a biologically and chemically significant classification of metal ions. Environ Pollut Ser B Chem Phys 1:3-26

Nolan C, Dahlgaard H (1991) Accumulation of metal radiotracers by Mytilus edulis. Mar Ecol Prog Ser 70:165-174

Reinfelder JR, Fisher NS (1991) The assimilation of elements ingested by marine copepods. Science 251:794-796

Smale MJ (1996) Cephalopods as prey. IV. Fishes. Philos Trans R Soc Lond Ser B 351:1067-1081

Tanaka T, Hayashi Y, Ishizawa M (1983) Subcellular distribution and binding of heavy metals in the untreated liver of the squid; comparison with data from the livers of cadmium and silver exposed rats. Experientia (Basel) 39: 746-748

Taylor MG, Simkiss K (1984) Inorganic deposits in invertebrates tissues. Environ Chem 3:102-138

Ueda T, Nakahara M, Ishii T, Suzuki Y, Suzuki H (1979) Amounts of trace elements in marine cephalopods. J Radiat Res 20:338-342

Ueda T, Nakahara M, Nakamura R, Suzuki Y, Shimizu C (1985) Accumulation of ${ }^{65} \mathrm{Zn}$ by octopus Octopus vulgaris. J Radiat Res 26:313-320

Wallace WG, Lopez GR (1997) Bioavailability of biologically sequestered cadmium and the implications of metal detoxification. Mar Ecol Prog Ser 147:149-157

Wang WX, Fisher NS, Luoma SN (1996) Kinetic determination of trace element bioaccumulation in the mussel Mytilus edulis. Mar Ecol Prog Ser 140:91-113

Warnau M, Teyssié JL, Fowler SW (1996) Biokinetics of selected heavy metals and radionuclides in the common Mediterranean echinoid Paracentrotus lividus: seawater and food exposures. Mar Ecol Prog Ser 141:83-94

Wilkinson L (1990) Systat: the system for statistics. Systat, Evanston, IL

Whicker FW, Schultz V (1982) Radioecology: nuclear energy and the environment, Vol 2. CRC Press, Boca Raton, FL

Zar JH (1996) Biostatistical analysis, 3rd edn. Prentice-Hall, Upper Saddle River, NJ

Submitted: June 25, 2001; Accepted: October 30, 2001

Proofs received from author(s): March 22, 2002 